\title{
PENGARUH STATUS PENGUASAAN LAHAN TERHADAP PENDAPATAN PETANI PADI DI DESA TUMANI, KECAMATAN MAESAAN, KABUPATEN MINAHASA SELATAN
}

\author{
Meike Prisilia Manatar \\ Esry H. Laoh \\ Juliana R. Mandei
}

\begin{abstract}
This study aims to determine whether there is influence over land tenure status to the income of rice farmers. Data retrieval is done with primary data and secondary data. Primary data were obtained from the farmers through a list of questions that had been prepared, while secondary data obtained from the office of the village or the head of the village. The way of taking samples, to look at the total population of each of the existing land tenure status, then divided by the population over land ownership and divided by 60 as a sample to be taken. The data collection method used is descriptive analysis and ANOVA (analysis of variance) in one direction. The concepts of measuring variables used are over land ownership, production, farming costs, revenue and income. The results of this study indicate that there are significant land ownership to farmers' income, the highest income is income tenants. Different income is the income of farmers own property with tenant farmers' income.
\end{abstract}

Keywords: status of land tenure, income, rice farmer, Tumani Village, District of Maesaan, South Minahasa District

\section{ABSTRAK}

Penelitian ini bertujuan untuk mengetahui apakah terdapat pengaruh status penguasaan lahan terhadap pendapatan petani padi. Pengambilan Data dilakukan dengan pengambilan data primer dan data sekunder. Data primer diperoleh dari petani melalu daftar pertanyaan yang telah disiapkan, sedangkan data sekunder diperoleh dari kantor desa atau hukum tua. Cara pengambilan Sampel, dengan melihat jumlah populasi dari masing-masing status penguasaan lahan yang ada, kemudian dibagi dengan jumlah populasi status penguasaan lahan dan dibagi dengan 60 sebagai sampel yang akan diambil. Metode pengambilan data yang digunakan adalah analisis deskriptif dan analisis anova (analisis of varian) satu arah. Konsep pengukuran variabel yang digunakan adalah status penguasaan lahan, produksi, biaya usahatani, penerimaan dan pendapatan. Hasil penelitian ini menunjukkan bahwa terdapat pengaruh status penguasaan lahan terhadap pendapatan petani, pendapatan yang paling tinggi adalah pendapatan petani penyewa. Pendapatan yang berbeda adalah pendapatan petani milik sendiri dengan pendapatan petani penyewa.

Kata Kunci : Status Penguasaan Lahan, Pendapatan Petani, Padi, Desa Tumani, Kecamatan Maesaan, Kabupaten Minahasa Selatan

\section{PENDAHULUAN}

\section{Latar Belakang}

Lahan merupakan modal atau aset yang berharga untuk menjalankan usahataninya. Menurut Sadikin (2009) lahan memiliki dua fungsi dasar, yakni (1) fungsi kegiatan budaya, yang dapat dimanfaatkan untuk berbagai penggunaan, seperti permukiman (kawasan perkotaan maupun perdesaan), perkebunan, hutan produksi dan lain-lain, (2) fungsi lindung, yang ditetapkan dengan fungsi utama untuk melindungi kelestarian lingkungan hidup, mencakup sumberdaya alam, sumberdaya buatan, dan nilai sejarah budaya bangsa. Penggunaan lahan merupakan gambaran perilaku manusia untuk mencapai tujuan yang diinginkan. Lahan yang luas akan memperbesar harapan petani untuk hidup layak. Namun seiring dengan meningkatnya jumlah penduduk, keberadaan lahan terutama lahan pertanian menjadi semakin terancam karena desakan 
kebutuhan lahan yang lebih banyak. Sementara jumlah lahan yang tersedia tidak bertambah (Setyoko, 2013). Ada beberapa sebab yang bisa muncul diantaranya : (a) semakin terbatasnya ketersediaan tenaga bidang pertanian. Hal yang demikian sebenarnya bisa diatasi secara mekanis, namun tidak semua aktivitas budidaya tanaman pangan maupun tanaman lainnya bisa diatasi secara mekanis dalam pengelolaannya. (b) Rendahnya daya saing sektor pertanian dengan sektor di luar pertanian. (c) Keterbatasan lahan yang dimiliki oleh sebagian besar petani sehingga bagi petani yang berlahan sempit dalam mencukupi kebutuhan ekonomi rumah tangganya, maka perluasan penguasaan lahan perlu dilakukan, baik dengan cara menyewa, menggarap, menggadai maupun dengan cara numpang.

Mudakir (2011) mengungkapkan bahwa status penguasaan lahan dibagi menjadi tiga bagian, yaitu pemilik penggarap (owner operator), penyewa (cash tenant) dan bagi hasil (share tenant). Status penguasaan lahan yang berbeda secara teoritis akan menentukan tingkat keragaman usaha tani yang berbeda pula, yang dalam hal ini meliputi tingkat produktivitas lahan, pendapatan dan pengeluaran yang berlainan. Perbedaan status penguasaan lahan akan menentukan akses petani terhadap modal. Yang selanjutnya akan mempengaruhi faktor-faktor produksi yang digunakan dan pada akhirnya akan mempengaruhi produksi. Selain itu tingkat pendapatan dan tingkat efisiensi pada usahatani mereka akan berbeda pula.

Penelitian sebelumnya tentang sistem bagi hasil di Bengkulu, Pane (2014) mendapatkan sistem pembagian hasil panen antara petani pemilik lahan dan petani penggarap pada umumnya ditentukan berdasarkan produksi gabah yang dipanen. Jika hasil rendah $(<3600 \mathrm{~kg}$ gkp/ha), maka petani penggarap menerima $1 / 5$ bagian, jika hasil sedang (3600-4500 kg gkp/ha) maka petani penggarap menerima $1 / 6$ bagian, dan jika hasil tinggi (>4500 kg gkp/ha) maka petani penggarap menerima $1 / 7$ bagian. Sedangkan menurut Saptana (2002) dalam Irmayanti (2010) besarnya bagi hasil adalah besarnya upah yang diperoleh oleh setiap petani baik pemilik lahan maupun penggarap berdasarkan perjanjian atau kesepakatan bersama.

Desa Tumani Kecamatan Maesaan Kabupaten Minahasa Selatan adalah salah satu sentra produksi padi yang memiliki luas areal sawah sekitar 102,8 ha dengan produktivitas 51,4 $\mathrm{kw} / \mathrm{ha}$. Rata-rata pemilikan lahan sawah didesa ini adalah 0,40 Ha (2015). Pertambahan Penduduk menyebabkan pemilik lahan semakin kecil, bahkan sebagian petani sudah tidak memiliki lahan. Kondisi tersebut menyebabkan sebagian petani yang tidak memiliki lahan, mengusahakan lahan orang lain dengan sistem sewa dan bagi hasil.

\section{Rumusan Masalah}

Dari uraian latar belakang yang menjadi masalah dalam penelitian ini adalah bagaimana pengaruh status penguasaan lahan pada pendapatan petani padi di desa Tumani Kecamatan Maesaan Kabupaten Minahasa Selatan.

\section{Tujuan dan Manfaat Penelitian}

Penelitian ini bertujuan untuk mengetahui pengaruh status penguasaan lahan padi terhadap pendapatan petani di Desa Tumani Kecamatan Maesaan Kabupaten Minahasa Selatan. Sedangkan manfaat penelitian yakni memperoleh gambaran pengaruh status penguasaan lahan terhadap pendapatan petani padi serta memberikan informasi kepada pemerintah mengenai status penguasaan lahan dan pendapatan sehingga membantu dalam kebijaksanaan dan perencanaan yang lebih baik.

\section{METODOLOGI PENELITIAN}

Waktu dan Tempat Penelitian

Penelitian ini dilakukan di Desa Tumani Kecamatan Maesaan dan akan di mulai pada JuliNovember 2016.

\section{Metode Penelitian}

Metode yang digunakan dalam penelitian ini adalah metode survei dengan cara mengambil data primer dan data sekunder. Data primer diperoleh melalui daftar pertanyaan yang telah disiapkan, sedangkan data sekunder diperoleh dari kantor kecamatan, kantor desa, serta instansi yang terkait.

\section{Metode Pengambilan Sampel}

Populasi dalam penelitian ini adalah status penguasaan lahan (milik sendiri, sewa dan penggarap) sedangkan metode pengambilan sampel dilaksanakan dengan stratified Random Sampling dengan alokasi sebanding dan dari masing-masing strata ditarik sampel. Jumlah sampel dalam penelitian ini akan diambil 60 petani. Dengan sebaran sebagai mana Tabel 1. 
Tabel 1. Sebaran Populasi dan Sampel Status Penguasaan Lahan

\begin{tabular}{lcc}
\hline Status Pengusaan & Populasi & Sampel \\
\hline Milik Sendiri & 137 & 42 \\
Penyewa & 14 & 4 \\
Penggarap & 45 & 14 \\
\hline Total & 196 & 60 \\
\hline
\end{tabular}

Sumber : Diolah dari data primer 2016

\section{Konsepsi Pengukuran Variabel}

Adapun variabel-variabel yang diukur dalam penelitian ini adalah sebagai berikut :

1. Status penguasaan lahan yaitu lahan yang digarap atau diolah dalam usahatani yang dilihat dari cara pengusaan lahan petani pemilik, petani penyewa dan petani penyakap.

a. Petani pemilik ialah golongan petani yang bebas mengusahakan usahataninya.

b. Petani penyewa ialah golongan petani yang mengusahakan lahan orang lain dengan jalan menyewa, serta lamanya kontrak tergantung pada perjanjian antara pemilik lahan dan penyewa

c. Petani penggarap ialah golongan petani yang mengusahakan lahan orang lain dengan sistem bagi hasil. Dalam sistem bagi hasil resiko usahatani ditanggung oleh pemilik tanah dan penggarap.

2. Produksi yaitu jumlah padi yang dihasilkan dalam satu kali musim tanam yang diukur dalam Kg.

3. Biaya usahatani adalah biaya tetap dan biaya variabel

a. Biaya tetap adalah biaya yang sifatnya tidak dipengaruhi oleh besar kecilnya produksi, misalnya pajak tanah, biaya penyusutan alat, iuran air, sewa lahan dll.

b. Biaya variabel adalah biaya yang sifatnya dipengaruhi oleh besar kecilnya produksi, misalnya : biaya saprodi, biaya tenaga kerja dll.

4. Penerimaan adalah produksi yang diperoleh selama satu kali musim tanam dikalikan dengan harga yang dinyatakan dalam (Rp).

5. Pendapatan adalah selisih antara penerimaan dan biaya (Rp).

\section{Analisis Data}

Analisis yang digunakan pada penelitian ini adalah :
1. Analisis Pendapatan
$\mathrm{I}=\mathrm{R}-\mathrm{C}$

Keterangan $: \mathrm{I}=$ Pendapatan $(\mathrm{Rp})$

$$
\begin{aligned}
& \mathrm{R}=\text { Penerimaan }(\mathrm{Rp}) \\
& \mathrm{C}=\text { Biaya }(\mathrm{Rp})
\end{aligned}
$$

Penerimaan $(\mathrm{R}) \quad=$ Jumlah Produksi $(\mathrm{kg}) \mathrm{X}$ Harga $(\mathrm{Rp} / \mathrm{kg})$

Biaya Produksi $(\mathrm{C})=$ Biaya tetap + Biaya Variabel + Biaya Implisit

2. Analisis Varian (Anova) satu arah di ulangan yang tidak sama.

Hipotesis sebagai berikut: Rata-rata pendapatan petani pemilik, penyewa dan penggarap tidak sama. Secara statistik hipotesis tersebut dapat dirumuskan sebagai berikut:

$$
\begin{aligned}
& \text { H0 }: \mu_{1}=\mu_{2}=\mu_{3} \\
& \text { H1 } \text { : Sekurang-kurangnya ada satu nilai } \mu_{1} \\
& \text { yang berbeda. } \\
& \text { Keterangan : } \\
& \mu_{1}: \text { Milik Sendiri } \\
& \mu_{2}: \text { Penyewa } \\
& \mu_{3}: \text { Penggarap }
\end{aligned}
$$

Tabel 2. Analisis Penelitian

\begin{tabular}{cccc}
\hline \multirow{2}{*}{ Responden } & \multicolumn{3}{c}{ Status Penguasaan Lahan } \\
\cline { 2 - 4 } & Milik Sendiri & Penyewa & Penggarap \\
\hline 1 & $\mathrm{Y}_{11}$ & $\mathrm{Y}_{12}$ & $\mathrm{Y}_{13}$ \\
2 & $\mathrm{Y}_{21}$ & $\mathrm{Y}_{22}$ & $\mathrm{Y}_{23}$ \\
3 & $\mathrm{Y}_{31}$ & $\mathrm{Y}_{32}$ & $\mathrm{Y}_{33}$ \\
4 & $\mathrm{Y}_{41}$ & $\mathrm{Y}_{42}$ & $\mathrm{Y}_{43}$ \\
$\ldots$ & $\ldots$ & $\ldots$ & $\ldots$ \\
$\mathrm{N}$ & $\mathrm{Yn} 1$ & $\mathrm{Yn} 2$ & $\mathrm{Yn} 3$ \\
Jumlah & $\mathrm{Y} .1$ & $\mathrm{Y} .2$ & $\mathrm{Y} .3$ \\
\hline
\end{tabular}

a. Faktor Koreksi :

$\mathrm{FK}=\sum Y i j 2 / \mathrm{t} . \mathrm{r}$

b. Jumlah Kuadrat Total :

$\mathrm{JKT}=\left(\mathrm{Y}_{11}\right)^{2}+\left(\mathrm{Y}_{12}\right)^{2}+\ldots+\left(\mathrm{Y}_{\mathrm{i}}\right)^{2}-\mathrm{FK}$

c. Jumlah Kuadrat Perlakuan :

$\mathrm{JKP}=\frac{(\mathrm{Y} 1)^{2}}{r_{1}}+\frac{(\mathrm{Y} 2)^{2}}{r_{2}}+\frac{(\mathrm{Y} 3)^{2}}{r_{3}}-F K$

d. Jumlah Kuadrat Galat :

$\mathrm{JKG}=\mathrm{JKT}-\mathrm{JKP}$

e. Kuadrat Tengah Perlakuan :

$\mathrm{KTP}=\frac{\mathrm{JKP}}{\mathrm{db} \text { perlakuan }}$

f. Kuadrat Tengah Galat :

$\mathrm{KTG}=\frac{\mathrm{JKG}}{\mathrm{db} \text { galat }}$

g. Fhit perlakuan $=\frac{\text { KT Perlakuan }}{\text { KT Galat }}$

Keterangan :

$\mathrm{Y}_{1}=$ nilai pengamatan dari perlakuan ke-i pada kelompok atau perlakuan

$\mathrm{t}=$ perlakuanr

$\mathrm{i} \quad=$ ulangan perlakuan ke $\mathrm{i}$

$\mathrm{db}=$ derajat bebas 
Tabel 3. Analisis Anova

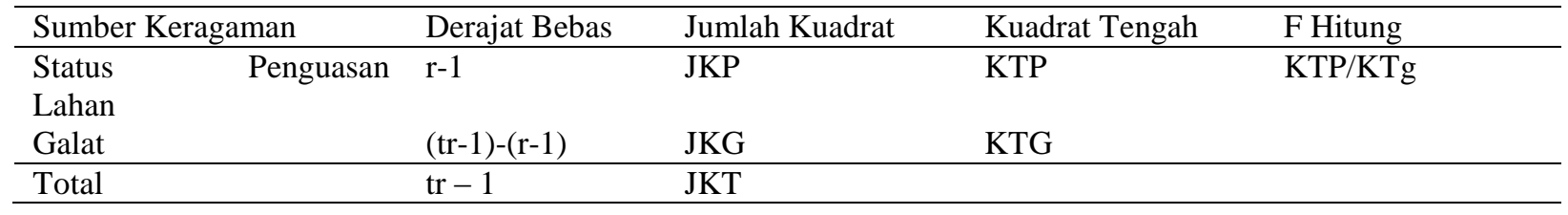

Kaidah Keputusan :

Jika $\quad \mathrm{F}_{\text {hitung }}>\mathrm{F}_{\text {tabel }}$; maka terima $\mathrm{H} 1$

$\mathrm{F}_{\text {hitung }}<\mathrm{F}_{\text {tabel }}$; maka terima $\mathrm{H} 0$

Selanjutnya dilanjutkan dengan uji Beda

Nyata Terkecil (BNT).

\section{HASIL DAN PEMBAHASAN}

\section{Karakteristik Petani Responden}

\section{Umur Petani}

Umur petani akan mempengaruhi produktivitas kerja atau perannya dalam pengambilan keputusan dari berbagai alternatif pekerjaan yang dilakukan. Umur petani memiliki hubungan dengan kemampuan petani dalam bekerja. Jika ditinjau dari segi fisik, semakin tua umur seseorang setelah melewati batas umur tertentu, maka semakin berkurang kemampuan untuk bekerja. Umur petani responden menurut hasil penelitian dapat dilihat dalam Tabel 4:

Tabel 4. Jumlah Responden berdasarkan kelompok umur

\begin{tabular}{ccc}
\hline $\begin{array}{c}\text { Umur Petani } \\
\text { (Tahun) }\end{array}$ & $\begin{array}{c}\text { Jumlah Petani } \\
\text { (Orang) }\end{array}$ & $\begin{array}{c}\text { Presentasi } \\
(\%)\end{array}$ \\
\hline $40-45$ & 19 & 31,67 \\
$46-50$ & 20 & 33,33 \\
$51-55$ & 8 & 13,33 \\
$56-60$ & 8 & 13,33 \\
$61-65$ & 5 & 8,33 \\
\hline Total & 60 & 100 \\
\hline
\end{tabular}

Sumber : Diolah dari data primer 2016

Dari Tabel 4, dapat dilihat bahwa kelompok umur 40-45 sebanyak 19 orang petani atau 31,67 persen dari total petani responden. Untuk kelompok umur 46-50 sebanyak 20 orang petani atau 33,33 persen dari total petani responden, untuk kelompok umur 51-55 sebanyak 8 orang petani atau 13,33 persen dari total petani responden, untuk kelompok umur 56-60 sebanyak 8 orang petani atau 13,33 persen dari total petani responden dan untuk kelompok umur 61-65 sebanyak 5 orang petani atau 8,33 persen dari total petani.

\section{Tingkat Pendidikan}

Pendidikan merupakan salah satu faktor penting dalam usaha peningkatan kualitas sumberdaya manusia, serta peningkatan kualitas intelektual dan wawasan seseorang. Pendidikan petani dapat diaplikasikan dalam usahatani yang dikelola. Berdasarkan hasil penelitian, tingkat pendidikan petani responden bervariasi mulai dari tingkat Sekolah Dasar (SD) sampai Sekolah Menengah Atas (SMA) dapat dilihat pada Tabel 5.

Tabel 5. Tingkat Pendidikan Dan Presentase petani responden.

\begin{tabular}{ccc}
\multicolumn{3}{c}{ responden. } \\
\hline Tingkat & $\begin{array}{c}\text { Jumlah Petani } \\
\text { (Orang) }\end{array}$ & Presentase (\%) \\
\hline Pendidikan & 20 & 33,33 \\
SD & 29 & 48,33 \\
SMP & 11 & 18.33 \\
SMA & 60 & $100 \%$ \\
\hline Total &
\end{tabular}

Sumber : Diolah dari data primer 2016

Tabel 5 menunjukkan bahwa dari 60 orang responden petani padi sawah, tingkat pendidikan responden paling banyak adalah SMP yaitu sebanyak 29 orang responden atau 48,33 persen, sedangkan untuk responden petani yang tingkat SD sebanyak 20 orang atau 33,33 persen, dan yang pendidikan SMA sebanyak 11 orang atau 18,33 persen.

\section{Jumlah Tanggungan}

Keluarga merupakan unit masyarakat terkecil dan biasanya terdiri dari beberapa orang yaitu ayah, ibu, dan anak-anak. Jumlah anggota keluarga merupakan salah satu faktor penunjang keberhasilan dalam berusahatani. Pada Tabel 6 dapat dilihat jumlah tanggungan keluarga dari petani Padi sawah di Desa Tumani Kecamatan Maesaan Kabupaten Minahasa Selatan.

Tabel 6. Jumlah Tanggungan Keluarga Petani Responden.

\begin{tabular}{ccc}
\hline $\begin{array}{c}\text { Jumlah Tanggungan } \\
\text { (Orang) }\end{array}$ & $\begin{array}{c}\text { Jumlah Petani } \\
\text { (Orang) }\end{array}$ & $\begin{array}{c}\text { Presentasi } \\
(\%)\end{array}$ \\
\hline 1 & 8 & 13,33 \\
2 & 25 & 41,67 \\
$\geq 3$ & 27 & 45 \\
\hline Total & 60 & 100 \\
\hline
\end{tabular}

Sumber : Diolah dari data primer 2016 
Dari Tabel 6, dapat dilihat bahwa dari 60 orang responden ada 8 petani responden atau 13,33 persen memiliki jumlah tanggungan 1 orang, 25 petani responden atau 41,67 persen memiliki jumlah tanggungan 2 dan ada 27 petani responden atau 45 persen memiliki jumlah tanggungan $\geq 3$. Pada umumnya anggota keluarga yang terhitung dalam jumlah tanggungan ini membantu dalam hal penyediaan tenaga kerja. Dengan demikian ketersediaan tenaga kerja dalam keluarga akan mempengaruhi penyerapan tenaga kerja dari luar keluarga. Tetapi dilain pihak makin banyak anggota jumlah keluarga maka makin besar pula biaya yang diperlukan untuk memenuhi keperluan keluarga.

\section{Luas lahan}

Luas lahan yang diolah petani sangat menentukan besar kecilnya hasil produksi. Luas lahan responden berkisar antara 0,3 Hektar sampai 3 Hektar menurut masing-masing status penguasaan lahan.

Tabel 7. Presentase Dan Luas Lahan Petani Responden.

\begin{tabular}{|c|c|c|}
\hline $\begin{array}{c}\text { Luas lahan } \\
\text { (Ha) }\end{array}$ & $\begin{array}{c}\text { Jumlah } \\
\text { responden }\end{array}$ & Presentase (\%) \\
\hline$<0,50$ & 12 & 20,00 \\
\hline $0,50-1,00$ & 29 & 48,33 \\
\hline$>1,00$ & 19 & 31,67 \\
\hline Total & 60 & 100 \\
\hline
\end{tabular}

Sumber : Diolah dari data primer 2016

Tabel 7 menunjukkan bahwa luas lahan yang paling banyak dimiliki petani responden yaitu 0,50-1,00 luas dengan jumlah responden 24 orang dengan jumlah presentase 48,33 persen.

\section{Faktor Produksi}

Usahatani padi sawah di Desa Tumani Kecamataan Maesaan melewati beberapa tahap sebagai berikut :

1. Pengolahan lahan, biasanya menyewa traktor sampai lahan siap ditanami.

2. Penanaman padi, selain dengan penyemaian juga ada sebagian petani yang langsung menanam padi dengan cara menyebarkan benih padi secara langsung. Ada juga penanaman benih padi secara langsung dengan mnggunakan jarak tanam tertentu.

3. Penyiangan, biasanya menggunakan manual dengan tangan atau dilakukan dengan cara penyiangan menggunakan pestisida untuk mengatasi gulma.

4. Pemberantasan hama dan penyakit
5. Panen, yang biasanya dilakukan secara borongan.

Tabel 8 menunjukkan bahwa petani penggarap menggunakan benih lebih banyak jika dibandingkan dengan petani dengan status penggunaan lainnya. Penggunaan pupuk paling banyak petani milik sendiri yaitu 277.85 namun bila dibandingkan dengan rekomendasi pupuk untuk tanaman padi per hektarnya yaitu untuk Urea sebesar $200 \mathrm{~kg}-250 \mathrm{~kg}$, SP36 $100 \mathrm{~kg}-150 \mathrm{~kg}$ dan $\mathrm{KCl} 75 \mathrm{~kg}-100 \mathrm{~kg}$ dan bila menggunakan NPK dosisnya adalah 100-150 kg urea dan 300kg NPK hal ini menunjukkan penggunaan pupuk yang efektif atau paling mendekati rekomendasi ada pada petani pemilik. Penggunaan pupuk di desa Tumani lebih besar dari penggunaan pupuk berdasarkan rekomendasi.

Penggunaan pestisida paling banyak digunakan oleh petani penyewa yaitu $60.99 \mathrm{ml}$ namun bila dibandingkan dengan rekomendasi pestisida untuk tanaman padi per hektarnya masih lebih kecil dari rekomendasi pestisida yaitu 750 ml pestisida.

\section{Produksi}

Produksi adalah hasil dari hasil produksi yang didapatkan dengan jumlah harga yang ditetapkan. Dalam hasil produksi yang didapatkan di desa Tumani hasil data produksinya dapat dilihat pada Tabel 9.

Data pada Tabel 9 menunjukkan bahwa produksi yang ada di masing-masing status penguasaan lahan ini berbeda, produksi padi $\mathrm{Kg} / \mathrm{Ha}$ yang paling tinggi adalah petani penyewa yaitu sebesar $4006.45 \mathrm{~kg} / \mathrm{Ha}$ dan paling rendah adalah petani dengan status milik sendiri yaitu 3 $429.29 \mathrm{~kg} / \mathrm{ha}$. Produktivitas tersebut masih lebih kecil jika dibandingkan dengan kondisi yang dilaporkan pada tahun 2015 di desa yang sama yaitu $5140 \mathrm{~kg} / \mathrm{ha}$, hal ini disebabkan karena penggunaan pupuk yang berlebihan.

\section{Biaya Produksi}

Biaya produksi adalah keseluruhan biaya yang dikeluarkan petani dalam satu kali musim tanam. Dalam usaha tani padi sawah, biaya produksi yang dimaksud adalah biaya sarana produksi (benih/bibit, pupuk), biaya sewa lahan dan biaya tenaga kerja. Dalam penelitian ini, biaya yang digunakan yaitu biaya variabel yang terdiri dari biaya saprodi dan biaya tenaga kerja. Berikut ini biaya Produksi Tanaman Padi Sawah. 
Tabel 10 menunjukkan bahwa total biaya produksi paling besar ada pada petani penyewa yaitu $\mathrm{Rp} 9,027,250.000$ dan paling rendah ada pada petani penggarap yaitu $\operatorname{Rp} 7,188,380.00$

Dalam Biaya Produksi Tanaman Padi Sawah ternyata ada biaya yang benar-benar dikeluarkan oleh masing-masing petani tersebut yang sebelumnya dihitung secara keseluruhan namun ada bagian-bagian yang memang ditanggung sendiri oleh petani yang bersangkutan dan berikut ini rekapitulasi biaya-biaya yang memang dikeluarkan oleh petani itu sendiri yang disebut dengan biaya ekspisit dan biaya implisit Tabel 11 akan menjelaskan rekapitulasi biaya eksplisit dan biaya implisit.

Dalam biaya eksplisit dan implisit dapat dilihat bahwa untuk biaya benih, berdasarkan sampel yang diambil petani milik sendiri dan petani penggarap pada umumnya mereka sudah mendapatkan bibit dari pemerintah sedangkan pada petani penyewa, dalam penelitian ditemukan masih ada yang membeli bibit dikarenakan mereka belum termasuk dalam bantuan pemerintah. Dengan demikian dapat dilihat berdasarkan penelitian yang dilakukan ternyata hampir sama biaya yang dikeluarkan oleh masingmasing petani berdasarkan status penguasaan lahan mereka, itu dapat dilihat dari upah tenaga kerja dan juga pupuk yang mereka keluarga, sedangkan ternyata ada biaya yang tidak dihitung yaitu biaya tenaga kerja dalam keluarga, tenaga kerja dalam keluarga sering menjadi salah satu hal yang tidak diperhitungkan dalam pendapatan usahatani.

\section{Penerimaan}

Penerimaan merupakan hasil produksi yang dikalikan dengan harga yang diterima oleh petani. Penerimaan yang diperoleh oleh masingmasing petani berbeda, tergantung dari jumlah produksi yang dihasilkan dan harga jual. Pada Tabel 12 di jelaskan tentang penerimaan rata-rata petani berdasarkan status penguasaan lahan.

Tabel 12 menunjukkan bahwa penerimaan usahatani paling tinggi adalah petani penyewa yaitu Rp. 21.679.316,13 dan paling rendah adalah petani milik sendiri yaitu Rp. 18.003.802,19. Jika dilihat dari penerimaan per-ha, yang paling tinggi adalah petani penyewa yaitu Rp. 21.679.316,13 dan paling rendah petani penggarap yaitu $\mathrm{Rp}$ 13.982.358,87. Dalam sistem bagi hasil ada kesepakatan $3 / 4$ untuk petani penggarap dan $1 / 4$ untuk petani pemilik.

\section{Pendapatan}

Pendapatan usahatani di peroleh dari selisih antara penerimaan usahatani dan biaya produksi dari usahatani. Dari hasil penelitian dapat diketahui bahwa pendapatan untuk masingmasing status penguasaan lahan seperti terlihat pada Tabel 13.

Pendapatan usahatani terbesar adalah petani penyewa yaitu Rp. 14.652.066,00 dan pendapatan yang terendah diperoleh oleh petani milik sendiri yaitu Rp 10.519.778,38 sedangkan pada pendapatan yang diterima petani $\mathrm{Rp} / \mathrm{Ha}$ menunjukkan bahwa pendapatan terbesar diperoleh oleh petani penyewa yaitu sebesar $\mathrm{Rp}$ 14.652.066,00 dan pendapatan yang terendah diperoleh oleh petani penggarap yaitu sebesar $\mathrm{Rp}$ 8.591.073,16.

Petani penyewa merupakan petani dengan pendapatan tertinggi hal ini dikarenakan dalam sistem kontrak pemilik dan sewaan kerugian ditanggung oleh petani yang bersangkutan sehingga petani penyewa berusaha untuk meningkatkan produktivitasnya guna untuk menutupi pengeluaran biaya produksi yang berlebihan sedangkan dalam kontrak bagi hasil ada kesepakatan antara pemilik dan penggarap, kesepakatannya yaitu penggarap berhak membayar proses produksi sedangkan pemilik membayar pajak lahan dan kebutuhan lain yang diperlukan pada saat proses produksi berlangsung. Dari hasil pendapatan ini dapat dilihat pendapatan yang diterima dipengaruhi oleh hasil produksi, penggunaan biaya benih, pupuk, pestisida, tenaga kerja, biaya borong traktor dan biaya panen yang akan mempengaruhi pendapatan dari ketiga status petani ini. Dan jika dilihat hasil analisis pada Lampiran 26, untuk pendapatan usahatani, hasilnya menunjukkan bahwa nilai F-hitung sebesar 4.55 nyata pada taraf signifikansi $5 \%$. Berarti perbedaan status penguasaan lahan akan menghasilkan pendapatan yang berbeda.

Selanjutnya untuk mengetahui perbandingan masing-masing pasangan perlakuan maka dilanjutkan dengan uji beda rata-rata. Uji beda rata-rata yang digunakan adalah Beda Nyata Terkecil (BNT), dapat dilihat pada Tabel 14.

Hasil analisis menggunakan anova menunjukkan bahwa petani dengan status penguasaan sewa memiliki pendapatan paling besar, pendapatan petani milik sendiri berbeda dengan pendapatan petani penyewa, pendapatan petani milik sendiri tidak berbeda nyata dengan petani penggarap, dan petani penyewa tidak berbeda nyata dengan petani penggarap. 
Jika dilihat hasil analisis Anova (Lampiran 27) untuk pendapatan yang benarbenar diterima oleh petani, hasilnya menunjukkan bahwa nilai F-hitung sebesar 8.79 nyata pada taraf signifikansi $5 \%$. Berarti perbedaan status pengusaan lahan yang berbeda akan menghasilkan pendapatan petani yang berbeda. Selanjutnya untuk mengetahui perbandingan masing-masing pasangan perlakuan maka dilanjutkan dengan uji beda rata-rata. Uji beda rata-rata yang digunakan adalah Beda Nyata Terkecil (BNT), dapat dilihat pada Tabel 15.

Uji beda rata-rata menunjukkan bahwa pendapatn petani paling tinggi adalah pada status pengusaan lahan penyewa, yang berbeda nyata dengan pendapatan petani penggarap dan milik sendiri.

Tabel 8. Penggunaan Faktor Produksi per-ha menurut Status Penguasaan Lahan

\begin{tabular}{lrrr}
\hline Faktor Produksi & Milik Sendiri & Penyewa & Penggarap \\
\hline Benih/bibit (kg) & 16.71 & 22.88 & 31.46 \\
Pupuk (kg) & 277.85 & 168.63 & 187.22 \\
Pestisida (ml) & 46.88 & 60.99 & 54.18 \\
Tenaga Kerja & & & \\
-Pembibitan (hok) & 3 & 2 & 3 \\
-Penanaman (hok) & 8 & 7 & 7 \\
- Hama dan Penyakit (hok) & 2 & 2 & 2 \\
- Pemupukan (hok) & 3 & 2 & 2 \\
- Penyiangan (hok) & 2 & 2 & 2 \\
\hline
\end{tabular}

Sumber : Diolah dari data primer (2016)

Tabel 9. Rata-rata Produksi Padi Berdasarkan Status Penguasaan Lahan

\begin{tabular}{lc}
\hline \multicolumn{1}{c}{ Status Penguasaan Lahan } & $\begin{array}{c}\text { Produksi } \\
(\mathrm{Kg} / \mathrm{Ha})\end{array}$ \\
\hline Milik Sendiri & 3429.29 \\
Penyewa & 4006.45 \\
Penggarap*) & 3551.08 \\
\hline
\end{tabular}

Sumber : Diolah dari data primer (2016)

*) untuk penggarap belum dikurangi

Tabel 10. Biaya Produksi Usahatani Tanaman Padi Sawah Berdasarkan Status Penguasaan Lahan

\begin{tabular}{lccc}
\hline \multirow{2}{*}{\multicolumn{1}{c}{ Jenis Biaya }} & \multicolumn{3}{c}{ Biaya Produksi Padi Sawah Berdasarkan } \\
& Milik Sendiri & Penyewa & Penggarap \\
\cline { 2 - 4 } & $32,123.02$ & - & - \\
\hline Biaya tidak tetap & $183,813.00$ & $251,625.00$ & $346,107.00$ \\
Benih/bibit & $1,528,167.00$ & $927,500.00$ & $1,029,714.00$ \\
Pupuk & $642,302.00$ & $835,625.00$ & $742,321.00$ \\
Pestisida & - & $2,000,000.00$ & - \\
Biaya Sewa & $1,523,810.00$ & $1,500,000.00$ & $1,535,714.00$ \\
Biaya Traktor & $2,500,000.00$ & $2,500,000.00$ & $2,500,000.00$ \\
Biaya Panen & $1,073,810.00$ & $1,012,500.00$ & $1,034,524.00$ \\
Tenaga Kerja & $\mathbf{7 , 4 8 4 , 0 2 5 . 0 2}$ & $\mathbf{9 , 0 2 7 , 2 5 0 . 0 0}$ & $\mathbf{7 , 1 8 8 , 3 8 0 . 0 0}$ \\
\hline Total Biaya & & &
\end{tabular}

Sumber : Diolah dari data primer (2016) 
Tabel 11 Rekapitulasi Biaya Ekspilisit dan Biaya Implisit Tanaman Padi Sawah berdasarkan status penguasaan lahan

\begin{tabular}{lccc}
\multicolumn{1}{c}{ Uraian } & \multicolumn{3}{c}{ Status Penguasaan Lahan } \\
\cline { 2 - 4 } & Milik Sendiri & Penyewa & Penggarap \\
\hline Biaya Eksplisit & $32,123.02$ & - & - \\
a. Biaya Tidak Tetap & $183,813.00$ & $251,625.00$ & $346,107.00$ \\
b. Benih & $1,528,167.00$ & $927,500.00$ & $1,029,714.00$ \\
c. Pupuk & $642,302.00$ & $835,625.00$ & $742,321.00$ \\
d. Pestisida & - & $2,000,000.00$ & - \\
e. Sewa Lahan & $1,523,810.00$ & $1,500,000.00$ & $1,535,714.00$ \\
f. Biaya Traktor & $2,500,000.00$ & $2,500,000.00$ & $2,500,000.00$ \\
g. Biaya Panen & $573,810.00$ & $532,500.00$ & $454,524.00$ \\
h. Tenaga Kerja LK & $\mathbf{6 , 9 8 4 , 0 2 5 . 0 2}$ & $\mathbf{8 , 5 4 7 , 2 5 0 . 0 0}$ & $\mathbf{6 , 6 0 8 , 3 8 0 . 0 0}$ \\
\hline Jumlah & & & \\
\hline Biaya Implisit & $\mathbf{4}$ & $480,000.00$ & $580,000.00$ \\
\multicolumn{1}{c}{ a. Tenaga Kerja Dalam } & $500,000.00$ & $\mathbf{4 8 0 , 0 0 0 . 0 0}$ & $\mathbf{5 8 0 , 0 0 0 . 0 0}$ \\
\hline Kumlah & $\mathbf{5 0 0 , 0 0 0 . 0 0}$ & $\mathbf{9 , 0 2 7 , 2 5 0 . 0 0}$ & $\mathbf{7 , 1 8 8 , 3 8 0 . 0 0}$ \\
\hline Jumlah & $\mathbf{7 , 4 8 4 , 0 2 5 . 0 2}$ &
\end{tabular}

Sumber : Diolah dari data primer (2016)

Tabel 12. Rata-rata Penerimaan Tanaman Padi Sawah Berdasarkan Status Penguasaan Lahan Status Penguasaan Lahan Penerimaan Usahatani/Ha Penerimaan yang dterima

\begin{tabular}{lcc} 
& petani/Ha \\
\hline Milik Sendiri & $18.003 .802,19$ & $18.003 .802,19$ \\
Penyewa & $21.679 .316,13$ & $21.679 .316,13$ \\
Penggarap (sudah dikurangi bagi & $18.643 .145,16$ & $13.982 .358,87$
\end{tabular}

hasil)

Sumber : Diolah dari data primer (2016)

Tabel 13. Rata-rata Pendapatan Petani Tanaman Padi Sawah berdasarkan Status Penguasaan Lahan

\begin{tabular}{lcc}
\hline Status Penguasaan Lahan & $\begin{array}{c}\text { Pendapatan Usahatani (Rp/Ha) } \\
\text { Pendapatan yang diterima Petani } \\
(\mathrm{Rp} / \mathrm{Ha})\end{array}$ \\
\hline Milik Sendiri & $10.519 .778,38$ & $10.519 .778,38$ \\
Penyewa & $14.652 .066,00$ & $14.652 .066,00$ \\
Penggarap & $11.454 .764,21$ & $8.591 .073,16$
\end{tabular}

Sumber : Diolah dari data primer (2016)

Tabel 14. Uji Beda Rata-Rata (BNT) Pendapatan Usahatani

\begin{tabular}{lccc}
\hline Status Lahan & N & Rata-rata & Grouping \\
\hline Milik Sendiri & 42 & $10,519,778.38$ & $\mathrm{~A}$ \\
Penggarap & 14 & $11,454,764.21$ & $\mathrm{AB}$ \\
Penyewa & 4 & $14,652,066.00$ & $\mathrm{~B}$ \\
\hline
\end{tabular}

Tabel 15. Uji Beda Rata-Rata (BNT) Pendapatan Petani

\begin{tabular}{lccc}
\hline Status Lahan & N & Rata-rata & Grouping \\
\hline Penggarap & 14 & $8,591,073.16$ & $\mathrm{C}$ \\
Milik Sendiri & 42 & $10,519,778.38$ & $\mathrm{~B}$ \\
Penyewa & 4 & $14,652,066.00$ & $\mathrm{~A}$ \\
\hline
\end{tabular}




\section{KESIMPULAN DAN SARAN}

\section{Kesimpulan}

Status penguasaan lahan mempengaruhi rata-rata pendapatan yang diterima oleh petani padi sawah. Rata-rata pendapatan yang paling tinggi adalah pada petani dengan status penguasaan lahan sewa. Pendapatan petani dengan status milik sendiri berbeda nyata dengan pendapatan petani penyewa namun tidak berbeda nyata petani milik sendiri dengan petani penggarap. Hal Dikarenakan penggunaan pestisida yang besar oleh petani penyewa.

Bila dilihat dalam rata-rata pendapatan yang diterima masing-masing petani menunjukkan adanya perbedaan yang nyata antara ketiga status penguasaan lahan petani milik sendiri, petani penggarap dan petani penyewa.

\section{Saran}

Bagi petani yang ingin mengusahakan tingkat produksi serta pendapatan yang tinggi sebaiknya menggunakan teknik pengolahan lahan petani penyewa agar lebih menguntungkan.

\section{DAFTAR PUSTAKA}

Affandi, Ismail \& Suhaimi (2013). Penyelesaian Sengketa Penguasaan Tanah Hak Guna Usaha (HGU) Perkebunan Kelapa Sawit Antara PT. Ubertraco/Nafasino dengan Masyarakat (Suatu Penelitian di Kabupaten Aceh Singkil). ISSN 2302-0180 Jurnal Ilmu Hukum Pascasarjana Universitas Syiah Kuala Terapan Vol. 2 No. 2

Daniel, M., 2002. Pengantar Ekonomi Pertanian. Penerbit PT Bumi Aksara, Jakarta

Gaspersz. V., 1994. Metode Perancangan Percobaan. Penerbit CV. ARMICO. Bandung
Hanafie, (2010). Pengantar Ekonomi Pertanian. Penerbit C.V Andi Offset. Yogjakarta

Herawati, (2012). Budidaya Padi. Penerbit PT Buku Kita. Jogjakarta

Irmayanti, (2010). Sistem bagi hasil antara pemilik usahatani lahan sawah di desa Bontotallasa Kecamatan Simvbang Kabupaten Maros. Jurusan Sosial Ekonomi Pertanian Fakultas Pertanian Universitas Hasanuddin Makasar

Meheda, D., 2015. Pemanfaatan lahan di bawah pohon kelapa dengan pola tanam tumpangsari di desa Poigar kecamatan Sinonsayang. Jurusan Sosial Ekonomi Pertanian Fakultas Pertanian Universitas Sam Ratulangi Manado

Meiliza, (2006). Pengaruh Pupuk Terrhadap Optimasi Produksi Padi Sawah Di Kabupaten Deli Serdang (Studi Kasus: Kelurahan Paluh Kemiri, Kecamatan Labuk Pakam). Departemen Sosial Ekonomi Pertanian Universitas Sumatera Utara Medan

Mudakir, B., (2011). Produktivitas Lahan dan Distribusi Pendapatan Berdasarkan Status Penguasaan Lahan Pada Usahatani Padi. Jurnal Dinamika Ekonomi Pembangunan, Volume 1, Nomor 1

Pambudi, (2008). Analisis Ekonomi Lahan (Land Rent) Pada Lahan Pertanian dan Permukiman di Kecamatan Ciampea. Program Studi Ekonomi Pertanian dan Sumberdaya Fakultas Pertanian Bogor.

Pane, (2014). Sistem Bagi Hasil dan Pendapatan Petani Padi Di Kabupaten Seluma Provinsi Bengkulu. Program Studi Agribisnis Jurusan Sosial Ekonomi Pertanian Fakultas Pertanian Universitas Bengkulu.

Pakpahan, A., N. (1992). Kelembagaan lahan dan konservasi tanah dan air. Pusat Penelitian Sosial Ekonomi Pertanian 
Sadikin, (2009). Analisis dampak konversi lahan pertanian terhadap produksi padi dan land rent. Departemen Ekonomi Sumberdaya Dan Lingkungan . Fakultas Ekonomi dan Manajemen Institut Pertanian Bogor.

Setyoko, (2013). Faktor-Faktor Yang Mempengaruhi Keputusan Petani Mengkonversi Lahan Pertanian Menjadi Lahan Non Pertanian. Fakultas Ekonomika dan Bisnis Universitas Di Ponegoro Semarang.

Tatuh, (2004). Ekonomi Institusional. Jurusan Sosial-Ekonomi Fakultas Pertanian Universitas Sam Ratulangi Manado
Tiku, (2008). Analisis Pendapatan Usahatani Padi Sawah Menurut System Mina Padi dan Sistem Non Mina Padi. Program Studi Manajemen Agribisnis Fakultas Pertanian Institut Pertanian. Bogor.

Undang-Undang Pokok Agraria (UUPA) Tahun 1960

Winarso, (2012). Dinamika Pola Penguasaan Lahan Sawah di Wilayah Pedesaan di Indonesia. ISSN 1410-5020 Jurnal Penelitian Pertanian Terapan Vol. 12 (3): 137-149 